\title{
SOSIALISASI KEAMANAN DAN KETERTIBAN MASYARAKAT OLEH POLISI RESORT KOTA DALAM MEMBENTUK SIKAP MASYARAKAT
}

\author{
Ridwan Setiawan Daradjat \\ SMK Negeri 2 Garut
}

\begin{abstract}
ABSTRAK
Tujuan penelitian yang dilakukan ialah untuk mengetahui penyebaran informasi sosialisasi Kamtibmas, peran Bagian Binamitra dan masyarakat dalam sosialisasi Kamtibmas, interaksi Bagian Binamitra dalam kegiatan Kamtibmas dengan masyarakat, partisipasi masyarakat dalam kegiatan Kamtibmas. Metode penelitian berupa deskriptif survei. Populasi yang dipilih sebagai responden secara acak ialah sebanyak 59 orang. Teori difusi inovasi diterapkan dalam penelitian ini, asumsinya bahwa pengetahuan seseorang diterpa kesadaran akan inovasi dan memperoleh pemahaman bagaimana fungsinya sehingga akan terbentuk sikap yang menyenangkan atau tidak menyenangkan terhadap inovasi. Hasil penelitian diantaranya: (1) Penyebaran informasi sosialisasi Kamtibmas yang dilakukan Bagian Binamitra Polresta Bandung Timur kepada masyarakat mengetahui adanya penyebaran informasi penyebaran informasi yang disampaikan sehingga mereka mengikuti sosialisasi yang diselenggarakan. (2) Peran Bagian Binamitra dan masyarakat dalam sosialisasi Kamtibmas yang baik dan bertanggung jawab atas keberlangsungan keamanan dan ketertiban di lingkungan masyarakat dan tingginya sikap masyarakat yang cenderung untuk lebih memotivasi, berpartisipasi, dan melaksanakan Kamtibmas di lingkungannya dengan efektif secara perorangan maupun bergotong royong dengan warga lainnya. (3) Interaksi Bagian Binamitra dalam kegiatan Kamtibmas dengan masyarakat, dilakukan baik secara langsung tatap muka, penyuluhan, maupun disampaikan melalui RW. dan RT. setempat dengan tingkat sedang masyarakat bersikap akan kegiatan interaksi tersebut. (4) Partisipasi masyarakat dalam kegiatan Kamtibmas dengan program kerja dan program kegiatan Binamitra yang membuat masyarakat cenderung aktif dan apresiatif dengan Binamitra untuk bersama-sama melakukan menjaga Kamtibmas yang berada di setiap kecamatan dan kelurahan.
\end{abstract}

Kata-kata kunci: Sosialisasi, peran, interaksi, sikap, masyarakat

\section{SOCIALIZATION OF PUBLIC SECURITY AND ORDERLINESS BY CITY AREA POLICE IN ESTABLISHING PUBLIC ATTITUDE}

\begin{abstract}
The purpose of this research is to identify the spread of information during Kamtibmas (acronym of keamanan dan ketertiban masyarakat or public security and orderliness) socialization, role of Bina Mitra (Partner development) in the socialization, interaction between Bina Mitra and the public in the Kamtibmas activities, and public participation in Kamtibmas activities. Descriptive survey method is implemented in this research; with total population randomly picked for respondents are 59 people. Diffusion innovation theory, implemented in this research, has an assumption that people consciousness on knowledge being exposed by innovation, in which people will understand that innovation as pleasant or unpleasant. Results of this research are: (1) Information dissemination on Kamtibmas socialization done by Bina Mitra of East Bandung Area Police is received and then intentionally participated by public. (2) Role of Bina Mitra and public in Kamtibmas socialization in the continuity of public security and orderliness and effectively motivates, participates, and implements Kamtibmas in their neighborhood, whether personally or in a group. (3) Interaction between Bina Mitra and public in the Kamtibmas activities is done by face-to-face, counseling, or through local area officials, with a medium level of response to it. (4) Public participation in Kamtibmas activities (action programs and Bina Mitra's activities program) is really high and appreciative, on protecting their neighborhood in each are they are living in.
\end{abstract}

Keywords: Socialization, the role of, interaction, attitude, the community

Korespondensi: Ridwan Setiawan Daradjat, S.Sos., M.I.Kom., SMK Negeri 2 Garut. Jl. Suherman No.90, Kecamatan Tarogong Kaler, Kabupaten Garut, Jawa Barat, 44151. Email: reedwanset@gmail.com 


\section{PENDAHULUAN}

Lingkungan merupakan daerah di mana sekumpulan masyarakat yang beraneka ragam tinggal dan berinteraksi antara satu dan lainnya. Lingkungan yang sehat, bersih, aman, dan tertib itulah yang diidamkan oleh warganya. Perlu dukungan kesadaran masing-masing warganya untuk mengkondisikan dirinya untuk bersikap tertib yang dapat dilakukan dengan cara bersikap kondusif, kooperatif dalam menjaga keamanan dan ketertiban lingkungan tersebut, atau dapat pula menjaga lingkungannya dengan membentuk sistem keamanan lingkungan (siskamling) atau keamanan ketertiban masyarakat (kamtibmas). Sistem inilah yang menjadi polemik di masyarakat yang dianggap hal yang tidak terlalu penting untuk dijalankan dan diterapkan dalam kehidupan sehari-hari di lingkungan tempat tinggalnya.

Mengantisipasi berbagai gangguan kamtibmas baik itu yang berkaitan dengan teror bom, tindakan kriminal yang bisa meresahkan warga masyarakat sampai penyalahgunaan narkoba yang dalam beberapa tahun terakhir ini menunjukkan peningkatan kepada taraf yang cukup mengkhawatirkan, jajaran Kepolisian pun melakukan sosialisasi langsung terhadap warga masyarakat yang berada di wilayah hukum Indonesia terutama kota Bandung. Hal ini diterapkan oleh jajaran Kepolisian di Polwiltabes, Polres Kota hingga Polsek Kota, dan kegiatan ini dilaksanakan selain mengacu kepada surat telegram Kapolda Jabar No. Pol.: ST/13/I/2005 tanggal 10 Januari 2005 yang dijadikan program kerja dan program kegiatan di setiap Bagian Binamitra (Humas) di setiap Polwiltabes dan Polres Kota Bandung. Pelaksanaan kegiatan sosialisasi tentang kamtibmas, narkoba, dan teror dilaksanakan di hotel-hotel, mall, perusahaan/instansi, tempat hiburan sertasekolah-sekolah di wilayahkota dan kabupaten Bandung. Adapun materi sosialisasi mengenai tindakan bila terjadi gangguan kamtibmas, sosisalisasi tentang bahaya narkoba sampai materi arahan kewilayahan seperti pentingnnya pendataan tempat kost yang tidak menutup kemungkinan bisa dijadikan markas oleh orang-orang yang tidak bertanggung jawab untuk melakukan tindakan kejahatan ataupun teror yang bisa merugikan masyarakat.
Mengenai masalah penyalahgunaan narkoba, sosialisasi lebih ditekankan kepada para remaja terutama para pelajar dan mahasiswa karena keberadaan mereka sangat menentukan nasib bangsa.

Pihak berwenang yang selalu mensosialisasikan dengan cara mengingatkan dan menghibau kepada masyarakat untuk menjalankan siskamling atau kamtibmas di lingkungannya agar aman dan terkendali. Peran sosialisator inilah yang menjadi deskripsi kerja pihak berwenang tersebut. Adalah Bagian Binamitra Polres Kota Bandung Timur yang merupakan pihak berwenang terhadap masyarakat yang harus menjadi aman dan tertib dibawah koordinasi Subbag Babinkamtibmas/ Bimmas yaitu Sub Bagian dalam Humas atau Binamitra Polres Kota Bandung Timur yang tugasnya mensosialisasikan, membina dan menyuluhkan keamanan ketertiban masyarakat wilayah Bandung Timur yang bersifat preventif (mengajak) masyarakat di lingkungan tersebut untuk tertib dan mengamankan masyarakatnya terhadap lingkungannya sendiri.

Binamitra merupakan bagian yang sebagai media antara perusahaan dengan publik internal yaitu orang-orang yang berada atau terkait dengan perusahaan atau instansi. Tujuan khusus Humas diantaranya sebagai penasehat bagi semua pihak yang membutuhkan data berdasarkan penelitian dan analisa yang dilakukan, membimbing bagian-bagian bawahannya dalam menjalankan tugas kerjanya, berhubungan dengan media sebagai juru bicara dalam konferensi pers dan kegiatan lain yang serupa, menyusun laporan tahunan untuk dipublikasikan, menyelenggarakan kegiatan berupa peringatan, perayaan, open house, kongres dan kegiatan lainnya bagi perusahaan atau instansi maupun untuk masyarakat, membuat dokumentasi dan mengumpulkan informasi sebagai sarana komunikasi internal maupun eksternal.

Bagian Binamitra merupakan departemen yang memang tugas kerjanya sebagai menjalin dan menjaga hubungan masyarakat dan hubungan instansi pemerintah dalam hal ini instansi kepolisian Polres Kota Bandung Timur. Tugasnya membina masyarakat di wilayah Bandung Timur. Sosialisasi yang dilakukan dengan menggunakan media cetak 
yang diterbitkan oleh redaksi dari Polwiltabes Bandung 'Warta Polisi', talkshow di media radio dan publikasi luar ruang.

Adapun sosialisasi yang dilakukan efektif dan efisien, perlu dilihat situasi dan kondisi publik atau masyarakat yang harus diberikan sosialisasi agar maksud dan tujuan yang ada dalam sosialisasi tersebut tepat sasaran dan berhasil diterima oleh publik atau masyarakat yang menjadi sasaran sosialisasi tersebut.

Penelitian ini dilakukan melihat kondisi di masyarkat yang senantiasa masih kurang memiliki kesadaran akan keamanan dan ketertiban di lingkungannya. Banyak faktor yang menjadi pemicu timbulnya gangguan keamanan di lingkungan seperti kurangnya mengadakan kewaspadaan terhadap pergaulan sosial yang notabene pergaulan sosial itu yang merupakan sikap yang sesuai akan memungkinkan seseorang untuk memperolah persetujuan sosial dari orang sekitarnya. Pernyataan sikap tertentu akan dihargai oleh orang yang dianggap penting seperti orang tua, atasan, teman, dan lain-lain. Dalam sosialisai yang efektif dan efisien tersebut, sikap untuk menghargai sesama orang lain perlu diungkapkan sehingga terbina kerukunan sesama warga dan berakibat sosialisasi tersebut dapat terlihat efeknya kamtibmas pun dapat terlaksana sesuai yang direnacanakan dan diharapkan.

Kamtibmas yang telah menjadi Program Kerja dan Program Kegiatan dari Bagian Binamitra tersebut dapat dijadikan panutan bagi masyarakat bahwa kamtibmas yang sedang dijalankan tersebut dianggap menjadi kegiatan positif bagi Bagian Binamitra itu sendiri dan juga bagi masyarakat agar lingkungan tempat tinggalnya menjadi aman dan tertib.

Bagian Binamitra yang berfungsi sebagai Humas dalam kepolisian terutama di Polres Kota Bandung Timur dalam menjalankan sosialisasinya menggunakan pendekatan yang didukung oleh masyarakat pula.

Dalam Undang-undang Kepolisian Negara Republik Indonesia Nomor 2 Tahun 2002 pada Bab III pasal 13 disebutkan bahwa Tugas Kepolisian Negara Republik Indonesia adalah memelihara keamanan dan ketertiban masyarakat. Dan rumusan tugas pokok Polri tersebut dapat tersirat bahwa tugas Kepolisian selain sebagai institusi negara yang bertugas dalam bidang pelayanan jasa keamanan, perlindungan hukum, tetapi juga bekerja dalam kegiatan sosial kemasyarakatan yang mengedepankan tugas kemanusiaan.

Kegiatan eksternal Public Relations (Humas) dalam Bagian Binamitra Polres Kota Bandung Timur ini bertujuan untuk memperoleh citra positif dan menumbuhkan sikap positif dari masyarakat dalam menangani masalah kamtibmas, untuk tetap terjalin hubungan baik dengan masyarakat di wilayah hukum Bandung Timur untuk tetap berperan aktif dan berpartisipasi dalam masalah kamtibmas. Berbagai cara dapat dilakukan dalam sosialisasi ini yang diantaranya dilakukan dengan penyebaran informasi yang merata, peran aktif dan partisipasi masyarakat, pemberdayaan sektor-sektor penting seperti sumber daya alam dan sumber daya manusia yang ada di lingkungan masing-masing masyarakat.

Penyebaran informasi kamtibmas yang disosialisasikan tersebut dilakukan secara merata ke seluruh lingkungan masyarakat yang memiliki keragaman budaya, pemahaman, tingkat pendidikan, dan lain-lain, sehingga kamtibmas dapat secara efektif dan efisien dalam penyelenggaraannya. Hal itu juga dimaksudkan untuk dapat menekan tingkat tindakan kriminalitas di wilayah hukum kota dan kabupaten Bandung dan disertai pula dukungan dan partisipasi dari warga masyarakat dalam masalah siskamling dengan sendirinya dapat menutup serta mempersempit gerak langkah orang atau pihak yang akan melakukan tindakan kriminalitas.

Terlaksananya kegiatan Kamtibmas tersebut tidak lepas dari peran Bagian Binamitra yang menjadi Humas Kepolisian di Polres Kota Bandung Timur yang menjadi penggerak dalam pelaksanaan kegiatan Kamtibmas di wilayah hukum Bandung Timur. Peran tersebut merupakan tugas kerja sebagai aparat penegak hukum dalam melaksanakan keamanan dan ketertiban yang ada di lingkungan masyarakat khususnya dan lingkungan kota pada umumnya. Kesemuanya itu tidak terlepas dari partisipasi masyarakat yang dilibatkan dalam kegiatan kamtibmas tersebut sehingga masyarakat merasa bagian dari pengamanan di lingkungannya dari gangguaan keamanan berupa tindak kriminal yang akan timbul. Partisipasi yang baik timbul 
dengan bentuk sikap kooperatif masyarakat dalam keterlibatannya dari kegiatan Kamtibmas yang disosialisasikan secara efektif oleh Bagian Binamitra Polresta Bandung Timur, seperti aktif mengadakan kegiatan siskamling, penertiban penyakit masyarakat (pekat), menggalakan kegiatan keagamaan, menjaga kesehatan lingkungan dan psikologi masyarakat misalnya sikap toleransi terhadap tetangga, aktif mengadakan kegiatan sosial yang didukung oleh perusahaan yang ada di lingkungannya, dan lain sebagainya.

Pertanyaan penelitian dari latar belakang yang telah diungkapkan sebelumnya adalah sebagai berikut: (1) Bagaimana penyebaran informasi sosialisasi Kamtibmas yang dilakukan Bagian Binamitra Polresta Bandung Timur kepada masyarakat. (2) Bagaimana peran Bagian Binamitra dan masyarakat dalam sosialisasi Kamtibmas. (3) Bagaimana interaksi Bagian Binamitra dalam kegiatan Kamtibmas dengan masyarakat. (4) Bagaimana partisipasi masyarakat dalam kegiatan Kamtibmas. Tujuan penelitian ini diantaranya yaitu: (1) Mengetahui penyebaran informasi sosialisasi Kamtibmas yang dilakukan Bagian Binamitra Polresta Bandung Timur kepada masyarakat. (2) Mengetahui peran Bagian Binamitra dan masyarakat dalam sosialisasi Kamtibmas. (3) Mengetahui interaksi Bagian Binamitra dalam kegiatan Kamtibmas dengan masyarakat. (4) Mengetahui partisipasi masyarakat dalam kegiatan Kamtibmas.

\section{METODE PENELITIAN}

Metode dalam penelitian ini menggunakan metode deskriptif survei, penelitian deskriptif didefinisikan sebagai penelitian terhadap status, sikap, pendapat kelompok individu, perangkat kondisi dan prosedur, suatu sistem pemikiran atau peristiwa dalam rangka membuat deskripsi atau gambaran secara sistematik dan analitik yang dapat digunakan untuk memecahkan suatu masalah aktuil pada masa kini (Suprapto, 2013:13). Penelitian survei yaitu penelitian untuk mendapatkan gambaran tentang faktafakta dari gejala seperti pendapat masyarakat, keadaan sosial, ekonomi, politik, sikap serta karakteristik demografi dari suatu kelompok individu (Suprapto, 2013: 14). Alasan menggunakan metode tersebut dalam penelitian ini dikarenakan sosialisasi sikapmasyarakatakan Kamtibmas yang digambaran secara sistematik namun peneliti tanpa melakukan pengujian hipotesis. Penelitian ini juga menggunakan cara survei, yang mana data primer yang diperlukan diperoleh dari 59 responden secara acak dengan mengisi angket.

Populasi dalam setiap penelitian sangat berhubungan erat dengan masalah yang diteliti. Populasi adalah keseluruhan dari unit analisis yang ciri-cirinya akan diduga. Dan dijelaskan bahwa populasi merupakan keseluruhan elemen atau bagian yang akan ditarik kesimpulan berdasarkan hasil penelitian.

Kemudian diperjelas oleh bahwa populasi adalah wilayah generalisasi yang terdiri atas, objek atau subjek yang memiliki kuantitas dan karakteristik tertentu yang ditetapkan oleh peneliti untuk dipelajari dan kemudian ditarik kesimpulan (Sugiono, 2002: 55). Dari kedua ungkapan tersebut terlihat bahwa populasi dalam penelitian merupakan objek atau subjek yang akan diteliti dan ditentukan sebelumnya sesuai dengan tujuan dari suatu penelitian (Ruslan, 2004: 133).

Sesuai dengan penelitaian yang dilakukan untuk mengetahui Sosialisasi Kamtibmas Polres Kota Bandung Timur dalam kegiatan eksternal Humas, yang dimaksud populasi dalam penelitian ini adalah masyarakat yang tinggal dan atau berada di lingkungan wilayah hukum Bandung Timur, berada di 10 Kecamatan dengan karakakteristik yaitu pernah mengetahui dan pernah mengikuti kegiatan Kamtibmas di lingkungannya, aktif dalam kelompok sadar Kamtibmas yang ada di lingkungannya, membuat pos keamanan, portal penutup jalan, polisi tidur yang efektif, dan perangkat keamanan dan ketertiban lainnya yang berada di lingkungannya (Data Bagian Binamitra Polres Bandung Timur, Januari 2007). Berdasarkan referensi Peraturan Daerah Kota Bandung Nomor 06 tahun 2006 mengenai Pemekaran dan Pembentukan wilayah kerja Kecamatan dan Kelurahan di lingkungan pemerintah kota Bandung oleh Walikota Bandung membuat wilayah Bandung Timur memiliki 10 Kecamatan dan 41 Kelurahan (Arsip Binamitra, 2007: 6).

Penulis mengambil populasi dari 
kalangan pejabat Kecamatan dan Kelurahan serta masyarakat yang mengetahui dan pernah mengikuti sosialisasi Kamtibmas di lingkungannya yaitu berjumlah sekitar 70 orang (Data Bagian Binamitra Polres Bandung Timur, Maret 2007) tersebut yang memenuhi persyaratan karakteristik responden yaitu secara garis besarnya.

Maka jumlah sampel yang diperoleh dalam peneilitian ini adalah sebagai berikut:

Sampel $=0,84 \times 70$

$$
\begin{aligned}
& =58,8 \text { yang dibulatkan menjadi } 59 \\
& \quad \text { orang }
\end{aligned}
$$

Selain menggunakan rumus sebelumnya, dapat juga menggunakan rumus Yamane (Rakhmat, 1999: 82) dengan presisi kurang lebih $95 \%$ tingkat kepercayaannya, yaitu:

$$
\mathrm{n}=\frac{\mathrm{N}}{\mathrm{Nd}^{2}+1}
$$

Keterangan:

n : Sampel

$\mathrm{N} \quad$ : Populasi

d : Presisi

$\mathrm{n}=\frac{70}{(70)(0.05)^{2}+1}$

$=59,57$ kemudian peneliti membulatkan menjadi 59 responden.

Teknik pengumpulan data dalam penelitian ini adalah: (1) Angket yang dibuat merupakan daftar pertanyaan yang merupakan data primer penelitian, penelitian yang dilakukan oleh peneliti dengan cara mengajukan pertanyaan yang disusun secara sistematis dan angket ini bersifat tetutup karena alternatif jawaban telah disediakan oleh peneliti dlam lembar angket. Kemudian angket ini disebarkan dan diberikan secara tertulis kepada responden yaitu masyarakat yang berada di wilayah hukum Bandung Timur yang menjadi responden dari masalah yang diteliti. (2) Observasi yang dilakukan oleh peneliti untuk memperoleh data dengan cara melakukan peninjauan penelitian serta sekaligus melengkapi data-data yang dibutuhkan, yang dilakukan adalah observasi non participant. Sebelum mengumpulkan data yang diperlukan untuk peneliti mengadakan observasi langsung ke objek penelitian yaitu Polres Kota Bandung
Timur Bagian Binamitra. Observasi pada Bagian Binamitra atau Departemen Humas adalah agar peneliti mendapatkan data resmi tentang sosialisasi kamtibmas yang merupakan kegiatan eksternal Bagian Binamitra Polres Kota Bandung Timur dengan pihak-pihak eksternalnya. (3) Wawancara secara langsung yang dilakukan peneliti pada pihak-pihak yang terkait dengan penelitian yang dilakukan oleh peneliti yaitu wawancara dengan para personil kesatuan Bagian Binamitra Polres Kota Bandung dan responden (masyarakat yang berada di wilayah hukum Bandung Timur) untuk mendapatkan informasi dengan mengajukan pertanyaan secara lisan atau verbal secara langsung. (4) Studi Kepustakaan yang digunakan peneliti dengan cara mencari data pelengkap dengan mempelajari, memaknai, dan memahami buku sumber atau referensi lain yang terkait dengan masalah yang sedang diteliti dan sebagai penunjang serta pelengkap datadata yang dibutuhkan untuk penelitian ini oleh peneliti.

Angket penelitian disebarkan kepada responden yang berjumlah 59 orang yang menjadi sampel dalam penelitian ini. Adapun angket tersebut terdiri dari 8 pertanyaan, terbagi dalam 5 pertanyaan mengenai data responden, dan 19 pertanyaan mengenai penelitian yang peneliti lakukan.

Adapun kategori sosialisasi keamanan dan ketertiban Polres Kota Bandung Timur dalam membentuk sikap masyarakat terhadap keamanan dan ketertiban lingkungan yaitu: (1) Untuk variabel I yaitu sosialisasi keamanan dan ketertiban Polres Kota Bandung Timur memiliki dimensi:

Pertama, penyebaran informasi sosialisasi Kamtibmas, terdiri dari 2 pertanyaan dengan skala penilaian 5 sampai 1, didapat jawaban responden dengan pemberian skor setiap jawaban dengan bentuk kategorisasi 3 skala berikut:

\begin{tabular}{ccc}
\hline No. & $\begin{array}{c}\text { Interval Sub } \\
\text { Variabel Penyebaran } \\
\text { Informasi Sosialisasi } \\
\text { Kamtibmas }\end{array}$ & Kategori \\
\hline 1 & $2-4$ & Rendah \\
\hline 2 & $5-7$ & Sedang \\
\hline 3 & $>7$ & Tinggi \\
\hline
\end{tabular}


Kedua, peran secara efektif kepada masyarakat, terdiri dari 3 pertanyaan dengan skala penilaian 5 sampai 1, didapat jawaban responden dengan pemberian skor setiap jawaban dengan bentuk kategorisasi 3 skala berikut:

\begin{tabular}{ccc}
\hline No. & $\begin{array}{c}\text { Interval Sub Variabel } \\
\text { Peran Secara Efektif } \\
\text { Kepada Masyarakat }\end{array}$ & Kategori \\
\hline 1 & $3-6$ & Rendah \\
\hline 2 & $7-10$ & Sedang \\
\hline 3 & $>10$ & Tinggi \\
\hline
\end{tabular}

Ketiga, interaksi dalam sosialisasi Kamtibmas, terdiri dari 3 pertanyaan dengan skala penilaian 5 sampai 1, didapat jawaban responden dengan pemberian skor setiap jawaban dengan bentuk Kategorisasi 3 skala berikut:

\begin{tabular}{ccc}
\hline No. & $\begin{array}{c}\text { Interval Sub Variabel } \\
\text { Interaksi Dalam } \\
\text { Sosialisasi Kamtibmas }\end{array}$ & Kategori \\
\hline 1 & $3-6$ & Rendah \\
\hline 2 & $7-10$ & Sedang \\
\hline 3 & $>10$ & Tinggi \\
\hline
\end{tabular}

Keempat, partisipasi masyarakat dalam Kamtibmas, terdiri dari 4 pertanyaan dengan skala penilaian 5 sampai 1, didapat jawaban responden dengan pemberian skor setiap jawaban dengan bentuk Kategorisasi 3 skala berikut:

\begin{tabular}{ccc}
\hline No. & $\begin{array}{c}\text { Interval Sub } \\
\text { Variabel Partisipasi } \\
\text { Masyarakat Dalam } \\
\text { Kamtibmas }\end{array}$ & Kategori \\
\hline 1 & $4-8$ & Rendah \\
\hline 2 & $9-13$ & Sedang \\
\hline 3 & $>13$ & Tinggi \\
\hline
\end{tabular}

2. Untuk variabel II yaitu membentuk sikap masyarakat terhadap keamanan dan ketertiban lingkungan memiliki dimensi:
Pertama, aspek kognitif, terdiri dari 3 pertanyaan dengan skala penilaian 5 sampai 1 , didapat jawaban responden dengan pemberian skor setiap jawaban dengan bentuk Kategorisasi 3 skala berikut:

\begin{tabular}{ccc}
\hline No. & $\begin{array}{c}\text { Interval Aspek } \\
\text { Kognitif }\end{array}$ & Kategori \\
\hline 1 & $3-6$ & Rendah \\
\hline 2 & $7-10$ & Sedang \\
\hline 3 & $>10$ & Tinggi \\
\hline
\end{tabular}

Kedua, aspek afektif, terdiri dari 2 pertanyaan dengan skala penilaian 5 sampai 1 , didapat jawaban responden dengan pemberian skor setiap jawaban dengan bentuk Kategorisasi 3 skala berikut:

\begin{tabular}{ccc}
\hline No. & $\begin{array}{c}\text { Interval Aspek } \\
\text { Afektif }\end{array}$ & Kategori \\
\hline 1 & $2-4$ & Rendah \\
\hline 2 & $5-7$ & Tinggi \\
\hline 3 & $>7$ & Sedang \\
\hline
\end{tabular}

Ketiga, aspek konatif, terdiri dari 2 pertanyaan dengan skala penilaian 5 sampai 1 , didapat jawaban responden dengan pemberian skor setiap jawaban dengan bentuk Kategorisasi 3 skala berikut:

\begin{tabular}{ccc}
\hline No. & $\begin{array}{c}\text { Interval Aspek } \\
\text { Konatif }\end{array}$ & Kategori \\
\hline 1 & $2-4$ & Rendah \\
\hline 2 & $5-7$ & Tinggi \\
\hline 3 & $>7$ & Sedang \\
\hline
\end{tabular}

Setelah analisis data responden yang peneliti lakukan sebelumnya kemudian dilakukan analisis data dari pertanyaan yang peneliti teliti mengenai sosialisasi keamanan dan ketertiban polres kota Bandung Timur dalam membentuk sikap masyarakat. Analisis deskriptif ini peneliti menggunakan tabel silang untuk hasilnya penghitungannya dari data responden yang disilangkan dengan data 
pertanyaan.

Analisis data responden pada tabel 1 sampai dengan tabel 5 yang menampilkan data responden, dalam hal ini pejabat Kecamatan dan Kelurahan serta masyarakat di wilayah Bandung Timur yang diketahui mengikuti sosialisasi Kamtibmas berdasarkan arsip Binamitra Polres Kota Bandung Timur pada bulan Maret 2007. Data responden meliputi, jenis kelamin, usia, pendidikan terakhir, pekerjaan, pendapatan. Adapun data mengenai penelitian tersebut meliputi sikap masyarakat terhadap keamanan dan ketertiban lingkungan dari aspek kognitif, afektif, dan konatif, dan keseluruhan tabel disertai analisis data sebagai berikut:

Tabel 1 Jenis Kelamin Responden

\begin{tabular}{cccc}
\hline No. & $\begin{array}{c}\text { Jenis } \\
\text { Kelamin }\end{array}$ & $\mathbf{F}$ & $\mathbf{\%}$ \\
\hline 1. & Pria & 48 & 81,35 \\
\hline 2. & Wanita & 11 & 18,65 \\
\hline & Jumlah & 59 & 100 \\
\hline
\end{tabular}

Tabel 1 menunjukkan 59 responden mayoritas berjenis kelamin Pria yaitu sejumlah 48 orang (81,35 \%), sedangkan selebihnya adalah responden berjenis kelamin Wanita sejumlah 11 orang $(18,65 \%)$. Hal ini mengungkapkan bahwa masyarakat atau warga yang mengetahui, aktif dalam kegiatan Kamtibmas dididominasi oleh kaum Pria. Dari tabel tersebut, terlihat bahwa kaum Pria lebih mengetahui dan aktif serta berpartisipasi dalam kegiatan Kamtibmas Binamitra Polres Kota Bandung Timur dari Kecamatan dan Kelurahan di Bandung.

Hasil tersebut juga sesuai dengan data yang berada di Bagian Binamitra Polres Kota Bandung Timur per bulan Maret 2007. Dalam data tersebut dicantumkan bahwa warga yang mengetahui kegiatan Kamtibmas di wilayah hukum Bandung Timur adalah berjenis kelamin Pria sebesar $70 \%$ yang menjadi mayoritas dari kaum Wanita yang berjumlah 30 \% (Bagian Binamitra Polresta Bandung Timur, 2007).
Tabel 2 Usia Responden

\begin{tabular}{cccc}
\hline No. & Usia & F & \% \\
\hline 1. & $20-30$ tahun & 7 & 11,86 \\
\hline 2. & $30-40$ tahun & 11 & 18,65 \\
\hline 3. & $40-50$ tahun & 22 & 37,28 \\
\hline 4. & $>50$ tahun & 19 & 32,21 \\
\hline & Jumlah & 59 & 100 \\
\hline
\end{tabular}

Tabel 2 menunjukkan bahwa mayoritas dididominasi responden berusia antara 40 sampai 50 tahun sejumlah 22 orang $(37,28$ $\%)$, pada urutan kedua adalah responden yang berusia lebih dari 50 tahun sejumlah 19 orang $(32,21 \%)$, pada urutan ketiga adalah responden yang berusia 30 sampai 40 tahun sejumlah 11 orang $(18,65 \%)$, pada urutan terakhir adalah responden yang berusia 20 sampai 30 tahun sejumlah 7 orang $(11,86 \%)$. Ditarik kesimpulan bahwa didominasi untuk usia responden yang menjadi mayoritas dalam melaksanakan kegiatan Kamtibmas di wilayah Bandung Timur khususnya di lingkungannya masingmasing yaitu berusia 30 sampai 40 tahun karena usia yang terbilang produktif adalah di usia 30 sampai 40 tahun sehingga kegiatan kamtibmas dapat dilakukan dengan penuh semangat. Sedangkan dari data Bagian Binamitra Polres Kota Bandung Timur sendiri tercantum usia yang paling aktif dalam melaksanakan kegiatan Kamtibmas di wilayah Bandung Timur adalah usia 40 sampai dengan 50 tahun.

Di usia tersebut merupakan usia yang mengalami masa pensiun dan lebih banyak waktu luangnya sehingga waktu untuk melaksanakan kamtibmasnya pun dapat terlaksana dengan baik dan terfokus tanpa ada pekerjaan atau kegiatan lain yang sangat penting. Pada usia 31 sampai dengan 40 adalah masa peningkatan karir (Kasali, 2007: 30).

Warga di wilayah Bandung Timur yang aktif dalam melaksanakan kegiatan Kamtibmas di lingkungannya. 
Tabel 3 Tingkat Pendidikan Responden

\begin{tabular}{llcc}
\hline No. & \multicolumn{1}{c}{$\begin{array}{c}\text { Tingkat } \\
\text { Pendidikan }\end{array}$} & F & \% \\
\hline 1. & SD & 0 & 0 \\
\hline 2. & SMP & 0 & 0 \\
\hline 3. & SMA & 8 & 13,56 \\
\hline 4. & Diploma & 16 & 27,12 \\
\hline 5. & Sarjana /S1 & 35 & 59,32 \\
\hline 6. & Pasca Sarjana/S2 & 0 & 0 \\
\hline 7. & $\begin{array}{l}\text { Program Doktor/ } \\
\text { S3 }\end{array}$ & 0 & 0 \\
\hline & Jumlah & 59 & 100 \\
\hline
\end{tabular}

Tabel 3 menjelaskan mayoritas didominasi responden yang aktif dalam kegiatan Kamtibmas di wilayah Bandung yang mendidominasi urutan teratas berdasarkan tingkat pendidikannya yaitu warga yang berpendidikan Sarjana/S1 yang berjumlah 35 orang $(59,32 \%)$, selanjutnya urutan kedua adalah warga yang berpendidikan Diploma berjumlah 16 orang $(27,12 \%)$, urutan selanjutnya warga yang berpendidikan SMA yang berjumlah 8 orang $(13,56 \%)$. Dari hasil penghitungan tingkat pendidikan diatas, ditarik kesimpulan bahwa warga yang paling aktif dalam menjalankan kegiatan Kamtibmas adalah warga yang memiliki tingkat pendidikan Sarjana (S1). Dengan tingkat pendidikan Sarjana (S1), responden lebih terbiasa melakukan hal-hal yang bersifat penerapan, praktikal langsung di lapangan daripada hal-hal yang bersifat teoritis dengan memerlukan pemikiran yang berat. Lain halnya dengan Kamtibmas yang dilakukan oleh warga yang berpendidikan Diploma lebih memiliki pola pikir yang praktis seperti halnya ketika memperoleh ilmu di perkuliahannya, sehingga menganggap bahwa Kamtibmas itu sendiri adalah kegiatan yang memerlukan tenaga yang banyak daripada tatapi ada juga responden yang berpartisipasi dikarenakan sudah menjadi tugas kerjanya dari instansi kecamatan maupun kelurahan. Sedangkan dalam instansi pemerintah tidak didapat responden yang berpendidikan dibawah SMA dan diatas Sarjana.
Tabel 4 Pekerjaan Responden

\begin{tabular}{llll}
\hline No. & Pekerjaan & F & \% \\
\hline 1. & PNS & 36 & 61,01 \\
\hline 2. & $\begin{array}{l}\text { Pegawai } \\
\text { Swasta }\end{array}$ & 5 & 8,48 \\
\hline 3. & $\begin{array}{l}\text { Pegawai } \\
\text { BUMN }\end{array}$ & 3 & 5,08 \\
\hline 4. & Wiraswasta & 4 & 6,79 \\
\hline 5. & TNI / Polisi & 2 & 3,38 \\
\hline 6. & Lain-lain & 9 & 15,26 \\
\hline & Jumlah & 59 & 100 \\
\hline
\end{tabular}

Tabel 4 diatas menunjukkan urutan pertama dalam pekerjaan responden yang berpartisipasi aktif dalam kegiatan Kamtibmas di lingkungannya yaitu Pegawai Negeri Sipil (PNS) sejumlah 36 orang (61,01\%), selanjutnya di urutan kedua yaitu Lain-lain sejumlah 9 orang $(15,26 \%)$, diurutan ketiga yaitu Pegawai Swasta sejumlah 5 orang $(8,48$ $\%$ ), pada urutan keempat yaitu responden yang bekerja sebagai Wiraswasta sejumlah 4 orang $(6,79 \%)$, Pegawai BUMN sejumlah 3 orang $(5,08 \%)$ dan responden berprofesi TNI / Polisi sejumlah 2 orang $(3,38 \%)$.

Pekerjaan Responden yang diteliti oleh peneliti, Responden yang lebih aktif dalam kegiatan Kamtibmas bersama Bagian Binamitra Polres Kota Bandung Timur adalah pekerjaan yang tidak memakan waktu luang banyak dan tidak terlalu disibukkan oleh pekerjaan rutinnya di luar lingkungan tempat tinggalnya, seperti PNS yang notabene kita mengetahui kinerjanya dalam instansi kelurahan dan kecamatan. Adapun pekerjaan yang benar-benar terkait dengan Kamtibmas ialah profesi TNI atau Polisi, tetapi dalam penelitian ini justru berada diurutan keenam. Hal ini dikarenakan di lingkungan warga yang berprofesi sebagai TNI atau Polisi hanya berjumlah hanya beberapa orang saja bahkan tidak ada (Bagian Binamitra Polresta Bandung Timur, 2007). Selebihnya berprofesi yang tidak terkait dengan masalah Kamtibmas, justru menyetujui akan keberlangsungan Kamtibmas di lingkungannya. 
Tabel 5 Pendapatan Responden Perbulan

\begin{tabular}{llll}
\hline No. & Pendapatan & F $\%$ \\
\hline 1. & $\begin{array}{l}\text { Kurang dari Rp. } \\
\text { 500.000,- }\end{array}$ & 0 & 0 \\
\hline 2. & $\begin{array}{l}\text { Rp. 500.000,- } \\
\text { 1.000.000,- }\end{array}$ & 7 & 11,86 \\
\hline 3. & $\begin{array}{l}\text { Rp. 1.000.000,- - } \\
\text { Rp. 1.500.000,- }\end{array}$ & 19 & 32,22 \\
\hline 4. & $\begin{array}{l}\text { Rp. 1.500.000,- - } \\
\text { Rp. 2.000.000,- }\end{array}$ & 24 & 40,67 \\
\hline 5. & $\begin{array}{l}\text { Lebih dari Rp. } \\
\text { 2.000.000,- }\end{array}$ & 9 & 15,25 \\
\hline Jumlah & 59 & 100 \\
\hline
\end{tabular}

Tabel 5 menunjukkan urutan pertama dalam pendapatan responden pada urutan pertama yaitu responden yang berpendapatan Rp. 1.000.000,sampai dengan 2.000.000,- sejumlah 24 orang $(40,67 \%)$ selanjutnya pada urutan kedua dengan pendapatan Rp. 1.000.000,- sampai dengan Rp. 1.500.000,- sejumlah 19 orang $(32,22 \%)$, pada urutan ketiga yaitu Responden yang berpendapatan lebih dari Rp. 2.000.000,sejumlah 9 orang $(15,25 \%)$, diurutan terakhir yaitu Responden sejumlah 7 orang $(11,86 \%)$ yang memiliki pendapatan antara Rp. 500.000,sampai dengan Rp. 1.000.000,-.

Dari pendapatan setiap bulannya dari Responden yang diteliti oleh peneliti, Responden yang lebih aktif dalam kegiatan Kamtibmas bersama Polres Kota Bandung Timur adalah dengan pendapatan yang tidak banyak atau kurang dari Rp. 500.000,- setiap bulannya. Sedangkan Responden yang memiliki pendapatan diatas Rp.500.000,- setiap bulannya dinilai aktif dalam kegiatan Kamtibmas bersama dengan Bagian Binamitra Polres Kota Bandung Timur di lingkungannya dilihat dari pendapatannya (Bagian Binamitra Polresta Bandung Timur, 2007).

\section{HASIL DAN PEMBAHASAN}

Analisis tabulasi silang sosialisasi keamanan dan ketertiban Polres Kota Bandung Timur dalam membentuk sikap masyarakat terhadap keamanan dan ketertiban lingkungan, analisis ini disusun berdasarkan data yang telah dikumpulkan dari responden terhadap angket yang diberikan untuk pembuatan tabulasi silang yang diakumulasikan antara kolom yang satu dengan kolom yang lainnya melalui tabel silang diutarakan keterkaitan antara variabel sosialisasi keamanan dan ketertiban Polres Kota Bandung Timur dengan variabel membentuk sikap masyarakat terhadap keamanan dan ketertiban lingkungan.

Hasil perhitungan data diperoleh dengan mengakumulasikan nilai skor pertanyaan pada masing-masing sub variabel dan dimensi serta dibagi menjadi 4 kategori sesuai dengan skala pengukuran sikap yang dipergunakan ialah Skala Likert, dengan teknik berdasarkan data ordinal, yaitu data yang berbentuk rangking atau peringkat. Adapun menurut Rakhmat, Skala Likert yang dikembangkan oleh Rensis Likert, dan sering disebut sebagai method of summated ratings, yang berarti nilai peringkat setiap jawaban atau tanggapan itu dijumlahkan sehingga mencapai nilai total. Skala Likert secara umum menggunakan peringkat lima angka penilaian, yaitu; (a) sangat setuju, (b) setuju, (c) ragu, (d) tidak setuju, dan (e) sangat tidak setuju. Urutan setuju atau tidak setuju dapat dibalik ukurannya, yaitu mulai dari sangat tidak setuju hingga ke sangat setuju, dan alternatif angka penilaian dalam skala Likert dapat bervariasi dari nilai 5 sampai 1 bahkan 3 sampai 9. (Rakhmat, 2005: 94).

Setelah analisis data responden yang peneliti lakukan sebelumnya kemudian dilakukan analisis data dari pertanyaan yang peneliti teliti mengenai "Sosialisasi Keamanan dan Ketertiban Polres Kota Bandung Timur dalam Membentuk Sikap Masyarakat terhadap Keamanan dan Ketertiban Lingkungan". Dalam analisis deskriptif ini peneliti menggunakan tabel silang untuk hasil penghitungan dari data responden yang disilangkan dengan data pertanyaan. Adapun analisis data dengan menggunakan tabel silang dari pertanyaan dari nomor 6 , sampai dengan 24 , yaitu dapat dilihat pada tabel 6 di halaman berikut.

Tabel 6 menunjukkan respons dari masyarakat mengenai Penyebaran informasi sosialisasi Kamtibmas di lingkungan tempat tinggal, dengan respons tertinggi sejumlah 53 orang $(89,83 \%)$ mengatakan seringnya Bianmitra melakukan penyebaran informasi mengenai Kamtibmas di lingkungannya sejumlah 57 orang $(96.61 \%)$. 
Tabel 6 Penilaian responden (Sikap Kognitif) terhadap Penyebaran Informasi Sosialisasi Kamtibmas

\begin{tabular}{|c|c|c|c|c|c|c|c|c|}
\hline \multirow{3}{*}{$\begin{array}{c}\text { Penyebaran } \\
\text { Informasi Sosialisasi } \\
\text { Kamtibmas }\end{array}$} & \multicolumn{6}{|c|}{ Kognitif } & \multirow{2}{*}{\multicolumn{2}{|c|}{ Total }} \\
\hline & \multicolumn{2}{|c|}{ Tinggi } & \multicolumn{2}{|c|}{ Sedang } & \multicolumn{2}{|c|}{ Rendah } & & \\
\hline & f & $\%$ & f & $\%$ & $\mathbf{f}$ & $\%$ & f & $\%$ \\
\hline Sering & 53 & 89.83 & 4 & 6.78 & 0 & 0.00 & 57 & 96.61 \\
\hline Jarang & 2 & 3.39 & 0 & 0.00 & 0 & 0.00 & 2 & 3.39 \\
\hline Tidak Pernah & 0 & 0.00 & 0 & 0.00 & 0 & 0.00 & 0 & 0.00 \\
\hline Total & 55 & 93.22 & 4 & 6.78 & $\mathbf{0}$ & 0.00 & 59 & 100 \\
\hline
\end{tabular}

Perbedaan dalam penyampaian pesan Kamtibmas dilihat dari bagaimana keterlibatan masyarakat terhadap informasi yang diberikan dan kegiatan Bagian Binamitra Polres Kota Bandung Timur diselenggarakan di lingkungannya. Komunikasi mengenai Kamtibmas yang efektif dapat dilihat dari bagaimana proses pendekatan Bagian Binamitra Polres Kota Bandung Timur kepada masyarakat, pesan yang disampaikan dikemas secara proporsional dengan persepsi masyarakat mengenai pentingnya Kamtibmas di lingkungan tempat tinggalnya, penggunaan media sebagai saluran interpersonal, partisipatif masyarakat dalam kegiatan Kamtibmas yang diselenggarakan.

Saluran maupun media yang mempengaruhi penyebaran informasi sesuai dengan model difusi informasi ini sangatlah berperan baik dan penting. Kegiatan Humas yang menyampaikan pesan melalui media massa maupun pembinaan dan penyuluhan dapat dengan efektif menyampaikan pesan sosialisasi Kamtibmas kepada masyarakat. Hal ini diklasifikasikan sebagai kegiatan publisitas dalam penelitian ini sebagai sosialisasi, dimana Humas sebagai komunikator yang mensosialisasikan Kamtibmas kepada masyarakat yang menjadi kegiatan eksternal humas. Frekuensi penyebaran informasi tersebut berpengaruh pada khalayak atau masyarakat, pengunaan yang proporsional dan efektif ini tergantung kemampuan Humas mencari dan melakukan kegiatan media relations (menjalin hubungan dengan media), seperti halnya ketika ada surat keputusan Kapolri mengenai Polisi Masyarakat (Polmas) atau Forum Kerjasama Polisi dan Masyarakat (FKPM) Binamitra langsung mensosialisasikan mengenai hal tersebut kepada Camat dan para Lurah di wilayah Bandung Timur.

Tabel 7 Penilaian responden (Sikap Afektif) terhadap Penyebaran Informasi Sosialisasi Kamtibmas

\begin{tabular}{|c|c|c|c|c|c|c|c|c|}
\hline \multirow{3}{*}{$\begin{array}{l}\text { Penyebaran Informasi } \\
\text { Sosialisasi Kamtibmas }\end{array}$} & \multicolumn{6}{|c|}{ Aspek Afektif } & \multirow{2}{*}{\multicolumn{2}{|c|}{ Total }} \\
\hline & \multicolumn{2}{|c|}{ Tinggi } & \multicolumn{2}{|c|}{ Sedang } & \multicolumn{2}{|c|}{ Rendah } & & \\
\hline & $\mathbf{F}$ & $\%$ & $\mathbf{F}$ & $\%$ & $\mathbf{F}$ & $\%$ & f & $\%$ \\
\hline Sering & 1 & 1.69 & 55 & 93.22 & 1 & 2.08 & 57 & 97.00 \\
\hline Jarang & 0 & 0.00 & 2 & 3.39 & 0 & 0.00 & 2 & 3.39 \\
\hline Tidak Pernah & 0 & 0.00 & 0 & 0.00 & 0 & 0.00 & 0 & 0.00 \\
\hline Total & 1 & 1.69 & 57 & 96.61 & 1 & 2.08 & 59 & 100 \\
\hline
\end{tabular}


Tabel 7 menunjukkan respons dari masyarakat mengenai penyebaran pesan yang frekuensinya sering responden bersikap biasa saja sejumlah 55 orang $(93.22 \%)$. Hal ini dipengaruhi oleh keterbatsan waktu yang dimiliki Binamitra Polres Kota Bandung Timur yang memiliki kinerja terhadap kegiatan lainnya sehingga dalam penyebaran informasi yang dilakukan rendah tetapi dengan adanya personel Babinkamtibmas yang ditempatkan di setiap kelurahan dapat membantu kinerja Binamitra dalam sosialisasi Kamtibmas tersebut.

Penyebaran informasi menurut Tondowidjojo merupakan pesan yang bermuatan informasi dan data-data yang disusun bertujuan agar diketahui dan dipahami oleh penerima. Informasi dan data-data itu khusus dimaksud untuk penerima tertentu. Sebaliknya, bila dimaksudkan untuk diketahui masyarakat umum, maka hal itu juga akan disesuaikan. Bila penerima pesan bersikap negatif, maka informasi itu akan ditolak. membanjirnya yang diantaranya (1) Kekeliruan dan kesalahan dapat mengembang, (2) Kesalahpahaman dapat selalu bertambah dan meningkat, (3) Laju informasi justru menjadi terhambat, (4) Penyaringan dan penolakan informasi merupakan akibat penentu prioritas, (5) Masalah menjadi saru dan tanggapan menjadi dangkal, (6) Pesan-pesan melalui saluran-saluran pararel cenderung ditolak, dan (7) Mengakibatkan kebingungan yang dapat menjadi sumber penolakan. (Tondowidjojo, 2002: 22).

Tabel 8 Penilaian responden (Sikap Konatif) terhadap Penyebaran Informasi Sosialisasi Kamtibmas

\begin{tabular}{|c|c|c|c|c|c|c|c|c|}
\hline \multirow{3}{*}{$\begin{array}{l}\text { Penyebaran Informasi } \\
\text { Sosialisasi Kamtibmas }\end{array}$} & \multicolumn{6}{|c|}{ Aspek Konatif } & \multirow{2}{*}{\multicolumn{2}{|c|}{ Total }} \\
\hline & \multicolumn{2}{|c|}{ Tinggi } & \multicolumn{2}{|c|}{ Sedang } & \multicolumn{2}{|c|}{ Rendah } & & \\
\hline & $\mathbf{F}$ & $\%$ & $\mathbf{F}$ & $\%$ & f & $\%$ & f & $\%$ \\
\hline Sering & 54 & 91.53 & 3 & 5.08 & 0 & 0.00 & 57 & 96.61 \\
\hline Jarang & 2 & 3.39 & 0 & 0.00 & 0 & 0.00 & 2 & 3.39 \\
\hline Tidak Pernah & 0 & 0.00 & 0 & 0.00 & 0 & 0.00 & 0 & 0.00 \\
\hline Total & 56 & 94.92 & 3 & 5.08 & $\mathbf{0}$ & 0.00 & 59 & 100 \\
\hline
\end{tabular}

Tabel 8 menunjukkan respons dari masyarakat mengenai aspek sikap yang menunjukkan bagaimana perilaku atau kecenderungan berperilaku yang ada dalam diri seseorang dan berkaitan dengan objek sikap yang dihadapinya yang merupakan hasil faktorfaktor kognitif dan lingkungannya menunjukkan sejumlah 54 orang $(91,53 \%)$ dengan bersikap cenderung mendukung dan mengetahui adanya penyebaran informasi yang disampaikan oleh Binamitra Polres Kota Bandung Timur. Hal ini dipengaruhi dari masyarakat yang menyadari akan pentingnya Kamtibmas di lingkungannya sehingga mereka mengikuti sosialisasi yang diselenggarakan oleh Binamitra Polres Kota Bandung Timur.

Sosialisasi tidak dapat dipisahkan dengan komunikasi, karena komunikasi sebagai alat sosialisasi, yaitu sebagai jembatan dalam proses penyebarluasan informasi program atau konsep-konsep baru yang disosialisasikan terhadap masyarakat. Oleh karena itu, komunikasi merupakan instrumen penting dalam sosialisasi norma-norma dan nilai-nilai baru (Nasution, 1996: 85).

Tabel 9 menunjukkan respons masyarakat mengenai peran Binamitra secara efektif dengan sikap kognitif responden memiliki penilaian yang baik dan tinggi mengenai peran Binamitra selaku Pehumas di Kepolisian yang berperan sesuai mottonya "melindungi dan melayani masyarakat", meskipun ditengah polemik dalam kasus-kasus ulah oknum personel Polisi itu sendiri, tetapi Binamitra berusaha menepis akan citra yang dibentuk oleh ulah oknum personel Polisi tersebut. 
Tabel 9 Penilaian responden (Sikap Kognitif) terhadap Peran Binamitra Secara Efektif Kepada Masyarakat

\begin{tabular}{|c|c|c|c|c|c|c|c|c|}
\hline \multirow{3}{*}{$\begin{array}{l}\text { Peran Secara Efektif } \\
\text { Kepada Masyarakat }\end{array}$} & \multicolumn{6}{|c|}{ Aspek Kognitif } & \multirow{2}{*}{\multicolumn{2}{|c|}{ Total }} \\
\hline & \multicolumn{2}{|c|}{ Tinggi } & \multicolumn{2}{|c|}{ Sedang } & \multicolumn{2}{|c|}{ Rendah } & & \\
\hline & f & $\%$ & $\mathbf{f}$ & $\%$ & f & $\%$ & f & $\%$ \\
\hline Baik & 55 & 93.22 & 4 & 6.78 & 0 & 0.00 & 59 & 100 \\
\hline Sedang & 0 & 0.00 & 0 & 0.00 & 0 & 0.00 & 0 & 0.00 \\
\hline Kurang & 0 & 0.00 & 0 & 0.00 & 0 & 0.00 & 0 & 0.00 \\
\hline Total & 55 & 93.22 & 4 & 6.78 & 0 & 0.00 & 59 & 100 \\
\hline
\end{tabular}

Tabel 10 Penilaian responden (Sikap Afektif) terhadap Peran Binamitra Secara Efektif Kepada Masyarakat

\begin{tabular}{|c|c|c|c|c|c|c|c|c|}
\hline \multirow{3}{*}{$\begin{array}{c}\text { Peran Secara } \\
\text { Efektif Kepada } \\
\text { Masyarakat }\end{array}$} & \multicolumn{6}{|c|}{ Aspek Afektif } & \multirow{2}{*}{\multicolumn{2}{|c|}{ Total }} \\
\hline & \multicolumn{2}{|c|}{ Tinggi } & \multicolumn{2}{|c|}{ Sedang } & \multicolumn{2}{|c|}{ Rendah } & & \\
\hline & f & $\%$ & $\mathbf{f}$ & $\%$ & $\mathbf{f}$ & $\%$ & $\mathbf{f}$ & $\%$ \\
\hline Baik & 1 & 1.69 & 57 & 96.61 & 1 & 2.08 & 59 & 100 \\
\hline Sedang & 0 & 0.00 & 0 & 0.00 & 0 & 0.00 & 0 & 0.00 \\
\hline Kurang & 0 & 0.00 & 0 & 0.00 & 0 & 0.00 & 0 & 0.00 \\
\hline Total & 1 & 1.69 & 57 & 96.61 & 1 & 2.08 & 59 & 100 \\
\hline
\end{tabular}

Tabel 10 menunjukkan respons dari masyarakat mengenai peran Binamitra dengan perannya mendapat tanggapan dengan sikap afektif masyarakat dengan jumlah 57 orang berpendapat sedan-sedang saja dalam menyikapi peran Binamitra selaku Pehumas dalam kepolisian, hal itu dikarenakan pertimbangan Binamitra tidak memiliki kekuatan untuk membentuk opini publik secar menyeluruh ke semua kalangan masyarakat dengan latar belakang yang berbeda-beda.

Hal tersebut sejalan dengan pendapat yang diungkapkan oleh Rosady Ruslan mengenai Humas bahwa:

Humas beraktivitas menyelenggarakan komunikasi timbal balik (two way communication) antara perusahaan atau lembaga dengan pihak publik untuk menciptakan saling pengertian dan dukungan bagi tercapainya suatu tujuan tertentu dengan memiliki kekuatan dalam membentuk opini publik, menghimpun pengertian antara lembaga yang diwakilinya dengan publik yang menjadi target sasarannya (Ruslan, 2004: 31).

Tabel11 padahalaman berikut menunjukkan bagaimana respons dari masyarakat mengenai peran Binamitra yang ditanggapi dengan sikap Konatif responden yaitu menanggapi bahwa peran Binamitra Polres Kota Bandung Timur peran yang baik dan bertanggung jawab atas keberlangsungan keamanan dan ketertiban di lingkungan masyarakat dan tingginya sikap masyarakat sejumlah 56 orang $(94,92 \%)$, hal ini dikarenakan masyarakat cenderung untuk lebih memotivasi, berpartisipasi, dan melaksanakan Kamtibmas di lingkungannya dengan efektif secara perorangan maupun bergotong royong dengan warga lainnya. 
Tabel 11 Penilaian responden (Sikap Konatif) terhadap Peran Binamitra Secara Efektif Kepada Masyarakat

\begin{tabular}{|c|c|c|c|c|c|c|c|c|}
\hline \multirow{3}{*}{$\begin{array}{l}\text { Peran Secara Efektif } \\
\text { Kepada Masyarakat }\end{array}$} & \multicolumn{6}{|c|}{ Aspek Konatif } & \multirow{2}{*}{\multicolumn{2}{|c|}{ Total }} \\
\hline & \multicolumn{2}{|c|}{ Tinggi } & \multicolumn{2}{|c|}{ Sedang } & \multicolumn{2}{|c|}{ Rendah } & & \\
\hline & f & $\%$ & f & $\%$ & f & $\%$ & f & $\%$ \\
\hline Baik & 56 & 94.92 & 3 & 5.08 & 0 & 0.00 & 59 & 100 \\
\hline Sedang & 0 & 0.00 & 0 & 0.00 & 0 & 0.00 & 0 & 0.00 \\
\hline Kurang & 0 & 0.00 & 0 & 0.00 & 0 & 0.00 & 0 & 0.00 \\
\hline Total & 56 & 94.92 & 3 & 5.08 & $\mathbf{0}$ & 0.00 & 59 & 100 \\
\hline
\end{tabular}

Peran Humas menurut Rumanti adalah menyelenggarakan dan bertanggung jawab atas penyampaian pesan informasi verbal maupun nonverbal kepada publik, memonitor dan mengevaluasi tanggapan serta pendapat masyarakat, tanggung jawab sosial pada semua kelompok yang berhak terhadap tanggung jawab tersebut sehingga citra yang kurang baik akan berubah membentuk baik. (Rumanti, 2002: 42).
Tabel 12 berikut menunjukkan respons dari masyarakat mengenai interaksi dalam sosialisasi Kamtibmas dengan interaksi yang menurut sikap responden adalah sering dan tertinggi dengan jumlah 46 orang $(77,97 \%)$. Hal ini dikarenakan bahwa masyarakat merasa terorganisir oleh Binamitra Polres Kota Bandung Timur dalam kegiatan Kamtibmas demi keamanan dan ketertiban di lingkungannya.

Tabel 12 Penilaian responden (Sikap Kognitif) terhadap Interaksi Dalam Sosialisasi Kamtibmas

\begin{tabular}{|c|c|c|c|c|c|c|c|c|}
\hline \multirow{3}{*}{$\begin{array}{c}\text { Interaksi Dalam } \\
\text { Sosialisasi Kamtibmas }\end{array}$} & \multicolumn{6}{|c|}{ Aspek Kognitif } & \multirow{2}{*}{\multicolumn{2}{|c|}{ Total }} \\
\hline & \multicolumn{2}{|c|}{ Tinggi } & \multicolumn{2}{|c|}{ Sedang } & \multicolumn{2}{|c|}{ Rendah } & & \\
\hline & f & $\%$ & $\mathbf{f}$ & $\%$ & $\mathbf{f}$ & $\%$ & f & $\%$ \\
\hline Sering & 46 & 77.97 & 3 & 5.08 & 0 & 0.00 & 49 & 83 \\
\hline Jarang & 9 & 15.25 & 1 & 1.69 & 0 & 0.00 & 10 & 16.95 \\
\hline Tidak Pernah & 0 & 0.00 & 0 & 0.00 & 0 & 0.00 & 0 & 0.00 \\
\hline Total & 55 & 93.22 & 4 & 6.78 & $\mathbf{0}$ & 0.00 & 59 & 100 \\
\hline
\end{tabular}

Menurut Wright dan Nasution, sosialisasi merupakan cara yang tepat dalam menyampaikan program kerja Humas dalam instansi Kepolisian mengenai Kamtibmas di masyarakat karena sosialisasi merupakan proses adaptasi penyebaran informasi atau konsep baru kepada masyarakat sehingga masyarakat mengetahui dan memahami terhadap informasi atau konsep baru tersebut. Sosialisasi tidak pernah "total" dan merupakan proses yang terus berlangsung - bergerak sejak masa kanak-kanak sampai tua Lebih lanjut, Wright menyatakan bahwa sejumlah besar sosialisasi dilakukan dengan sengaja, tetapi sosisalisasi juga terjadi secara tidak disadari ketika individu atau masyarakat mengambil petunjuk mengenai norma-norma sosial tanpa pengajaran khusus mengenai hal tersebut. (Wright, 1986: 182). 
Tabel 13 Penilaian responden (Sikap Afektif) terhadap Interaksi Dalam Sosialisasi Kamtibmas

\begin{tabular}{|c|c|c|c|c|c|c|c|c|}
\hline \multirow{3}{*}{$\begin{array}{c}\text { Interaksi Dalam } \\
\text { Sosialisasi Kamtibmas }\end{array}$} & \multicolumn{6}{|c|}{ Aspek Afektif } & \multirow{2}{*}{\multicolumn{2}{|c|}{ Total }} \\
\hline & \multicolumn{2}{|c|}{ Tinggi } & \multicolumn{2}{|c|}{ Sedang } & \multicolumn{2}{|c|}{ Rendah } & & \\
\hline & f & $\%$ & f & $\%$ & $\mathbf{f}$ & $\%$ & f & $\%$ \\
\hline Sering & 1 & 1.69 & 47 & 79.66 & 1 & 2.08 & 49 & 83 \\
\hline Jarang & 0 & 0.00 & 10 & 16.95 & 0 & 0.00 & 10 & 16.95 \\
\hline Tidak Pernah & 0 & 0.00 & 0 & 0.00 & 0 & 0.00 & 0 & 0.00 \\
\hline Total & 1 & 1.69 & 57 & 96.61 & 1 & 2.08 & 59 & 100 \\
\hline
\end{tabular}

Tabel 13 diatas menunjukkan respons dari responden mengenai interaksi antara pihak Binamitra dengan masyarakat menanggapi sering diadakannya interaksi dengan jumlah tanggapan 47 orang $(79,66 \%)$, interaksi ini dilakukan baik secara langsung tatap muka, penyuluhan, maupun disampaikan melalui RW. dan RT. setempat dengan tingkat sedang masyarakat bersikap akan kegiatan interaksi tersebut.
Effendy mengemukakan mengenai penyuluhan yaitu suatu metode komunikasi untuk meningkatkan keterampilan seseorang atau sejumlah orang dengan cara memberikan penjelasan yang disertai peragaan dengan menggunakan benda-benda nyata. Dalam Humas, penyuluhan dapat meningkatkan keterampilan petugas Humas itu sendiri mengenai aspek-aspek tertentu (Effendy, 2002: 34).

Tabel 14 Penilaian responden (Sikap Konatif) terhadap Interaksi Dalam Sosialisasi Kamtibmas

\begin{tabular}{|c|c|c|c|c|c|c|c|c|}
\hline \multirow{3}{*}{$\begin{array}{c}\text { Interaksi Dalam } \\
\text { Sosialisasi } \\
\text { Kamtibmas }\end{array}$} & \multicolumn{6}{|c|}{ Aspek Konatif } & \multirow{2}{*}{\multicolumn{2}{|c|}{ Total }} \\
\hline & \multicolumn{2}{|c|}{ Tinggi } & \multicolumn{2}{|c|}{ Sedang } & \multicolumn{2}{|c|}{ Rendah } & & \\
\hline & f & $\%$ & f & $\%$ & $\mathbf{F}$ & $\%$ & f & $\%$ \\
\hline Sering & 46 & 77.97 & 3 & 5.08 & 0 & 0.00 & 49 & 83 \\
\hline Jarang & 10 & 16.95 & 0 & 0.00 & 0 & 0.00 & 10 & 16.95 \\
\hline Tidak Pernah & 0 & 0.00 & 0 & 0.00 & 0 & 0.00 & 0 & 0.00 \\
\hline Total & 56 & 94.92 & 3 & 5.08 & $\mathbf{0}$ & 0.00 & 59 & 100 \\
\hline
\end{tabular}

Tabel 14 di atas menunjukkan tanggapan dari responden mengenai kecenderungan masyarakat dalam menyikapi interaksi yang dilakukan oleh Binamitra Polres Kota Bandung Timur dengan cara mengajak warga lainnya untuk ikut serta maupun menginformasikannya kepada warga akan kegiatan Kamtibmas dengan jumlah responden 46 orang $(77,97 \%)$ melakukan hal itu, berarti kegiatan interaksi yang dilakukan merupakan bentuk simpati dari masyarakat yang mengetahui akan pentingnya dan pernah mengikuti Kamtibmas di lingkungannya.

Seperti dalam tugas kerja Binamitra Polres Kota Bandung Timur, sosialisasi Kamtibmas adalah proses mengenalkan program kegiatan (progiat) dan program kerja (proja) Kamtibmas dan berperan serta dalam kegiatan tersebut secara efektif kepada masyarakat (Bagian Binamitra Polresta Bandung Timur, 2006). 
Tabel 15 Penilaian responden (Sikap Kognitif) terhadap Partisipasi Masyarakat dalam Kamtibmas

\begin{tabular}{|c|c|c|c|c|c|c|c|c|}
\hline \multirow{3}{*}{$\begin{array}{c}\text { Partisipasi } \\
\text { Masyarakat Dalam } \\
\text { Kamtibmas }\end{array}$} & \multicolumn{6}{|c|}{ Aspek Kognitif } & \multirow{2}{*}{\multicolumn{2}{|c|}{ Total }} \\
\hline & \multicolumn{2}{|c|}{ Tinggi } & \multicolumn{2}{|c|}{ Sedang } & \multicolumn{2}{|c|}{ Rendah } & & \\
\hline & $\mathbf{F}$ & $\%$ & f & $\%$ & f & $\%$ & f & $\%$ \\
\hline Sering & 48 & 81.36 & 3 & 5.08 & 0 & 0.00 & 51 & 86 \\
\hline Jarang & 7 & 11.86 & 1 & 1.69 & 0 & 0.00 & 8 & 13.56 \\
\hline Tidak Pernah & 0 & 0.00 & 0 & 0.00 & 0 & 0.00 & 0 & 0.00 \\
\hline Total & 55 & 93.22 & 4 & 6.78 & $\mathbf{0}$ & 0.00 & 59 & 100 \\
\hline
\end{tabular}

Tabel 15 menunjukkan respons dari masyarakat mengenai partipasi masyarakat menurut sikap Kognitifnya menunjukkan sering berpartisipasi sejumlah 48 orang $(81,36 \%)$ dalam kegiatan Kamtbimas yang diselenggarakan di lingkungannya.

Intensitas akan partispasi masyarakat di wilayah Bandung Timur merupakan cerminan respon positif dari masyarakat akan dukungannya terhadap keamanan dan ketertiban di lingkungannya sehingga tindak kriminalitas dapat diantisipasi dengan baik. Masyarakat secara aktif merespons sosialisasi yang diberikan oleh Bagian Binamitra dengan berupa siskamling secara berkala, melapor secara periodik akan kegiatan yang berkaitan dengan keamanan dan ketertiban di lingkungannya, membantu Bagian Binamitra ketika melaksanakan kegiatan yang berkaitan dengan keamanan dan ketertiban masayarakat.

Tabel 16 Penilaian responden (Sikap Afektif) terhadap Partisipasi Masyarakat dalam Kamtibmas

\begin{tabular}{|c|c|c|c|c|c|c|c|c|}
\hline \multirow{3}{*}{$\begin{array}{c}\text { Partisipasi } \\
\text { Masyarakat Dalam } \\
\text { Kamtibmas }\end{array}$} & \multicolumn{6}{|c|}{ Aspek Afektif } & \multirow{2}{*}{\multicolumn{2}{|c|}{ Total }} \\
\hline & \multicolumn{2}{|c|}{ Tinggi } & \multicolumn{2}{|c|}{ Sedang } & \multicolumn{2}{|c|}{ Rendah } & & \\
\hline & $\mathbf{f}$ & $\%$ & $\mathbf{f}$ & $\%$ & f & $\%$ & f & $\%$ \\
\hline Sering & 1 & 1.69 & 49 & 83.05 & 1 & 2.08 & 51 & 87 \\
\hline Jarang & 0 & 0.00 & 8 & 13.56 & 0 & 0.00 & 8 & 13.56 \\
\hline Tidak Pernah & 0 & 0.00 & 0 & 0.00 & 0 & 0.00 & 0 & 0.00 \\
\hline Total & 1 & 1.69 & 57 & 96.61 & 1 & 2.08 & 59 & 100 \\
\hline
\end{tabular}

Tabel 16 diatas menunjukkan respons dari masyarakat mengenai partipasi masyarakat dalam Kamtibmas secara konatif. responden menyikapi dengan sering berpartisipasi sejumlah 49 orang $(83,05 \%)$. Misalnya masyarakat berpartisipasi dengan cara ikut serta menjadi Polisi masyarakat yang merupakan program kegiatan Binamitra berdasarkan instruksi Kapolri.
Menurut Instruksi Kapolri tahun 2007 mengenai Forum Kemitraan Polisi dan Masyarakat (FKPM) mengutarakan bahwa tujuan terbentuknya Polisi Masyarakat (Polmas) adalah sebagai bentuk sistem keamanan dan ketertiban ditingkat RW maupun RT dalam lingkungan masyarakat (Bagian Binamitra Polresta Bandung Timur, 2006) 
Tabel 17 Penilaian responden (Sikap Konatif) terhadap Partisipasi Masyarakat dalam Kamtibmas

\begin{tabular}{|c|c|c|c|c|c|c|c|c|}
\hline \multirow{3}{*}{$\begin{array}{c}\text { Partisipasi } \\
\text { Masyarakat Dalam } \\
\text { Kamtibmas }\end{array}$} & \multicolumn{6}{|c|}{ Aspek Konatif } & \multirow{2}{*}{\multicolumn{2}{|c|}{ Total }} \\
\hline & \multicolumn{2}{|c|}{ Tinggi } & \multicolumn{2}{|c|}{ Sedang } & \multicolumn{2}{|c|}{ Rendah } & & \\
\hline & f & $\%$ & $\mathbf{f}$ & $\%$ & $\mathbf{f}$ & $\%$ & f & $\%$ \\
\hline Sering & 49 & 83.05 & 2 & 3.39 & 0 & 0.00 & 51 & 86 \\
\hline Jarang & 7 & 11.86 & 1 & 1.69 & 0 & 0.00 & 8 & 13.56 \\
\hline Tidak Pernah & 0 & 0.00 & 0 & 0.00 & 0 & 0.00 & 0 & 0.00 \\
\hline Total & 56 & 94.92 & 3 & 5.08 & $\mathbf{0}$ & 0.00 & 59 & 100 \\
\hline
\end{tabular}

Tabel 17 menunjukkan respons dari masyarakat mengenai partisipasi masyarakat dalam Kamtibmas yang disikapi secara Konatif berjumlah 49 orang $(83,05 \%)$ yang sering berpartisipasi dalam kegiatan Kamtibmas di lingkungannya bersama Binamitra Polres Kota Bandung Timur. Hal ini dikarenakan program kerja dan program kegiatan Binamitra dapat membuat masyarakat untuk cenderung aktif dengan Binamitra untuk bersama-sama melakukan kegiatan Kamtibmas. Bersama Babinkamtibmas yang berada di setiap kecamatan dan kelurahan.

Kamtibmas dilakukan untuk meminimalisir segala bentuk tindak kriminal, misalnya terorisme, pencurian kendaraan bermotor maupun barang berhargalainnya, tindak kriminal pada manusia (penculikan, pembunuhan, pemerkosaan, dan lain-lainnya), dan tindak kriminal lainnya. Selain itu kegiatan Kamtibmas itu dapat juga membangun citra positif dari Kepolisian yang selama ini dianggap kurang baik oleh masyarakat. Namun tujuan tersebut haruslah seefektif mungkin diwujudkan dengan dukungan sarana dan prasarana, kredibilitas, konsistensi semua pihak untuk melaksanakan kegiatan tersebut (Warta Polisi, 2006).

Untuk itulah masyarakat cenderung mengajak warga lainnya untuk aktif dalam kegiatan Kamtibmas bersama Binamitra Polres Kota Bandung Timur dan pihak terkait lainnya sehingga Kamtibmas yang telah direncanakan dan berjalan dapat dengan efektif hasilnya, dan tindakan kriminal sebisa mungkin diminimalisir.

\section{SIMPULAN}

Penyebaran informasi sosialisasi Kamtibmas yang dilakukan Bagian Binamitra Polresta Bandung Timur kepada masyarakat dengan intensitas sosialisasi Kamtibmas yang dilakukan dalam penyebarannya ialah jumlah responden yang menjawab setuju sejumlah 38 orang dengan persentase 64,41 \%. Dari persentase tersebut dapat diindikasikan bahwa intensitas dari sosialisasi Kamtibmas yang dilakukan oleh Polresta Bandung Timur sering dilakukan dengan baik sehingga masyrakat menyetujui bahwa sosialisasi Kamtibmas tersebut dilakukan di lingkungannya masingmasing. Intensitas sosialisasi yang dilakukan haruslah dengan menggunakan strategi yang menarik sehingga peserta atau masyarakat yang mengikuti kegiatan sosialisasi tersebut dapat antusias yang baik dan hasil sosialisasi tersebut dapat dengan mudah diaplikasi di lingkungan masyarakat. Pembinaan dan penyuluhan kepada masyarakat berdasarkan hasil survei dengan penilian tertinggi yang menjawab setuju ialah sejumlah 39 orang dengan persentase $66.10 \%$. Hasil tersebut menunjukkan bahwa pembinaan dan penyuluhan yang dilakukan oleh Binamita Polresta Bandung Timur merupakan rangkaian kegiatan ataupun rencana strategi (renstra) dari sosialisasi yang telah dilakukan sebelum kegiatan pembinaan dan penyuluhan tersebut dilakukan selanjutnya.

Peran secara efektif kepada masyarakat dalam sosialisasi Kamtibmas oleh Bagian Binamitra sebagai perlindung masyarakat dari tindak kriminal merupakan tugas utama dari kepolisian, dimana masyarakat sangat perlu akan perlindungan dari tindak kriminalitas atau kejahatan. Masyarakat yang menjadi objek perlindungan pun sudah sepatutnya taat akan hukum yang berlaku, baik itu pidana dan perdata. Pengetahuan hukum masyarakat dapat diperoleh dari peran serta kepolisian sebagai aparat penegak hukum, juga memberi 
teladan yang baik dalam aplikasinya di lingkungan masyarakat. Sosialisasi mengenai kamtibmas dapat dilakukan secara periodik berkesinambungan, agar masyarakat dapat mengetahui dan paham akan tindak kriminalitas dan teknis penegakan hukum secara pidana dan perdata. Banyak kasus main hakim sendiri yang dilakukan oleh masyarakat akan pelaku tindak kriminal sering kita jumpai di mediamedia massa. Meskipun tindakan main hakim sendiri tersebut bermaksud untuk memberi hukuman langsung agar si pelaku tindak kriminal tidak melakukannya lagi. Secara struktural, Babinkamtibmas ditempatkan di setiap polsek yang tersebar di seluruh wilayah Indonesia. Secara umum, ia menerangkan, seorang anggota Babinkamtibmas bertugas untuk memberikan penyuluhan hukum kepada masyarakat. Babinkamtibmas sebagai badan pembinaan keamanan ketertiban masyakat sudah sepatutnya berperan dalam melindungi masyarakat secara difensif dan secara hukum terhadap kriminalitas apapun itu bentuknya. Motto kepolisian Melindungi dan Melayani adalah alat pemicu untuk Bagian Binamitra yang benar-benar menjalankan fungsinya sebagai petugas Babinkamtibmas. Rangkaian kegiatan Kamtibmas yang dilaksanakan dari hulu hingga hilir dapat menimbulkan ketentraman di lingkungan masyarakat. Selain mensinergikan hal tersebut dengan masyarakat, juga diutamakan kewaspadaan dari masyarakat akan gejala-gejala timbulnya tindak kriminalitas di lingkungannya.

Interaksi Bagian Binamitra dalam kegiatan Kamtibmas dengan masyarakat dalam sosialisasi Kamtibmas yang dijalankan dilakukan dengan cara tatap muka secara personal, pembinaan, penyuluhan, dan gagasan baru sehingga terwujud pencapaian dalam menekan angka kriminalitas di lingkungan masyarakat. Masyarakatpun dalam kegiatan yang dilakukan Bagian Binamitra ketika sosialisasi Kamtibmas berlangsung untuk antusias dan kooperatif dalam pelaksanaannya di lingkungan masing-masing. Pelaksanaan kegiatan Kamtibmas secara rutin dan teratur dapat menimbulkan efek yang baik karena selain kontrol dari kepolisian setempat, juga kewaspadaan masyarakat akan tindak tanduk dari sang pelaku kriminalitas yang berada di lingkungan masyarakat. Pelacakan dari sinyal tindak kriminalitas dapat dilakukan dengan berbagai macam cara, selain investigasi juga dengan kegiatan Kamtibmas yang dilakukan untuk filter pertama untuk mencari bibit timbulnya tindak kriminalitas. Keterlibatan masyarakat dalam kegiatan Kamtibmas di lingkungannya sudah menjadi sasaran Binamitra untuk meminimalisir tindak kriminal yang tidak akan pernah berhenti didalam masyarakat. Tindakan preventif yang efektif akan menjadi tolak ukur bagi berhasil tidaknya keamanan dan ketertiban masyarakat di wilayah Bandung Timur. Interaksi yang diinginkan Binamitra ialah masyarakat saling bahu-membahu dengan Binamitra untuk menjalankan Kamtibmas di lingkungannya di wilayah Bandung Timur. Interaksi yang diinginkan masyarakat adalah kesetaraan dalam menjalankan kegiatan Kamtibmas di lingkungannya tidak membedakan status sosial.

Partisipasi masyarakat dalam kegiatan Kamtibmas dilakukan berupa Komunikasi dua atau lebih tahap dilakukan dengan efektif sehingga dalam penerapannya di lingkungan masyakat dapat terlaksana dengan optimal. Meskipun memerlukan biaya, tenaga, waktu yang tidak sedikit kamtibmas yang membutuhkan partisipasi masyarakat dapat menambah optimalisasi Kamtibmas di masingmasing lingkungan masyarakat. Evaluasi dari kegiatan Kamtibmas perlu dilakukan mengingat masih banyak kekurangan-kekurangan yang ada dalam pelaksanaan Kamtibmas. Kesadaran masyarakat akan pentingnya Kamtibmas sudah menjadi keharusan, karena untuk siapa lagi Kamtibmas tersebut dilakukan jika bukan untuk masyarakat itu sendiri. Memahami kegiatan Kamtibmas di lingkungannya dengan cara mengikuti sosialisasi yang dilakukan Bagian Binamitra dan menjalankan secara teknis serta prosedural apa yang menjadi keharusan dalam menjalankan Kamtibmas di lingkungan masyarakat itu sendiri. Salah satu cara partisipatif masyarakat dalam kegiatan Kamtibmas ini ialah antusias dalam mengikuti setiap kegiatan Kamtibmas yang diselenggarakan oleh Bagian Binamitra atau Babinkamtibmas di masing-masing lingkungan. Hal itu merupakan cerminan kepedulian masyarakat akan keberlangsungan Kamtibmas 
bagi lingkungannya agar dapat menekan tindakan kriminalitas, dengan meluangkan waktu untuk Kamtibmas di lingkungannya diharapkan untuk dapat mewujudkan keamanan dan ketertiban secara optimal.

Keikutsertaan masyarakat dalam kegiatan Kamtibmas yaitu dengan melakukan kegiatan yang sesuai dengan kapasitasnya sebagai warga sipil dengan hak dan kewajiban yang selaras dijalankan secara berkesinambungan. Secara periodik masyarakat mengikuti sosialisasi yang diselenggarakan dengan kegiatan yang berkaitan dengan Kamtibmas, misalkan kegiatan Siskamling, pembentukan Polisi Masyarakatyangjelas dengan deskripsikerjanya yang teratur dan terarah sesuai dengan yang diinstruksikan oleh pihak Binamitra itu sendiri. Sebagai gerakan antisipasi akan tindak kriminal yang secara nyata terlihat oleh masyarakat itu sendiri. Tinggal bagaimana Binamitra dapat dengan efektif mengaplikasikan program kerja dan kegiatannya bersama masyarakat untuk keberlangsungan keamanan dan ketertiban masyarakat.

Konsekuensi (consequences) dari pengalaman peristiwa difusi-inovasi yang utama pada akhirnya pernah digunakan (adoption) atau tidak dipergunakan (rejection). Misalnya jika adopsi Kamtibmas oleh RW. 08 diterapkan, tetapi RW. 03 tidak menerapkannya dan hal inilah yang disebut dengan konsekuensi dari sosialisasi yang dilakukan oleh Bagian Binamitra Polres Kota Bandung Timur.

Hal tersebut membutuhkan pemisahan dari fungsi-fungsi yang secara jelas dan harus dalam keadaan normal, yaitu mengenai urutan dari sumber komunikasi (communication resources), seperti terjadinya difusi-inovasi (penyebaran gagasan baru) berkaitan dengan pengetahuan. (Rosady, 2004: 121).

Anteseden dalam penelitian ini sejauhmana media massa atau saluran interpersonal sosialisasi Kamtibmas yang diaplikasikan dengan pembinaan dan penyuluhan (Binluh), kegiatan sholat Jum 'at Keliling dan kegiatan lainnya disosialisasikan dan dilaksanakan di wilayah hukum Bandung Timur yang kemudian ditunjukan dengan perhatian, pengertian, dan penerimaan dari masyarakat agar memperoleh kepuasan dan ketergantungan terhadap media yang mensosialisasikan Kamtibmas tersebut. Variabel media merupakan saluran interpersonal yang disalurkan melalui media massa, dalam variabel ini mengutarakan terpaan media, penggunaan media dan saluran interpersonal yang diaplikasikan dalam suatu kegiatan dilihat frekuensi pembinaan dan penyuluhan (Binluh) yang dilakukan Bagian Binamitra Polres Kota Bandung Timur dilakukan sebagai saluran interpersonal. Variabel efek difusi yang dioperasionalisasikan sebagai evaluasi kemempuan media untuk memberikan kepuasan, dependensi media yang menjadi bergantungnya komunikan terhadap media mana dan isinya, dapat berupa Temporal, yaitu menunjukkan pola adopsi gagasan baru dalam jangka waktu tertentu. Spasial, menunjukkan keteraturan tertentu dalam pola spasial distribusi inovasi. Struktur menunjukkan penyebaran informasi melalui sturktur-struktur komunikasi dalam dua tahap (two step) atau banyak tahap (multistep). Fasal mengacu pada fase-fase dalam proses adopsi, ada lima fase yang diantaranya pengenalan, informasi, evaluasi, percobaan, dan keputusan. (Bohlen, 1977).

Saran peneliti dari penelitian yang telah dilakukan diantaranya: penyebaran informasi sosialisasi Kamtibmas pesan yang disampaikan atau sebarkan dengan sosialisasi dengan penyuluhan, pesan harus sarat bermuatan informasi Kamtibmas lebih detail dan isinya pun harus mendeskripsikan bagaimana kegiatan Kamtibmas teknis pelaksanaannya. Penyuluhan dengan alat peragaan dan ilustrasi dapat menjadi nilai tambah bertujuan agar sikap masyarakat dapat menjadi positif. Penyebaran pesan Binamitra memonitor dan mengevaluasi tanggapan serta pendapat umum atau masyarakat. Petunjuk teknis yang jelas kepada masyarakat agar dapat mengaplikasikan di lingkungannya. Modal utama dalam hal penyebaran informasi ini adalah komunikasi timbal balik. Sebagai contoh Binamitra Polres Kota Bandung Timur memberikan informasi mengenai Kamtibmas kepada masyarakat dengan menggunakan media cetak, elektronik, luar ruang atau internet sehingga masyarakat mewaspadai akan bahaya akan terorisme dan bagaimana penanggulangannya secara multi media.

Peran bagian Binamitra Polres Kota Bandung Timur adalah menjadi garda depan dalam mensosialisasilan Kamtibmas untuk 
dapat diterapkan di lingkungan masyarkat. Peran lainnya ialah Binamitra juga menjadi pendamping masyarakat dalam menekan tindak kriminalitas yang ada di lingkungan masyarakat.

Interaksi dalam sosialisasi Kamtibmas tidaklah harus melihat status sosial dari masyarakatnya itu sendiri, bersikap netral ketika berinteraksi dalam menyelesaikan masalah Kamtibmas di wilayah hukum Bandung Timur. Kerjasama dengan pihak terkait ketika kegiatan Kamtibmas dilaksanakan adalah langkah yang selalu harus ditempuh agar dikemudian hari akses masuk untuk berinteraksi secara keseluruhan dapat terjalin dengan baik.

Partisipasi masyarakat dalam Kamtibmas menjadi indikasi keberhasilan bagi Binamitra, sebisa mungkin Binamitra menjaga hubungan baik melalui kegiatan-kegiatan yang dilakukan di lingkungan masyarakat. Masyarakat yang menjadi sasaran kegiatan haruslah patuh akan hukum terutama agar terciptanya Kamtibmas ini maka selayaknya masyarakat bersikap kooperatif dalam sosialisasi Kamtibmas yang diselenggarakan oleh Binamitra di lingkungan masyarakat.

\section{DAFTAR PUSTAKA}

Bagian Binamitra Polresta Bandung Timur. (2006). Data Kamtibmas.

Bagian Binamitra Polresta Bandung Timur. (2007). Data Kamtibmas.

Bohlen, M. J. (1977). The diffusion process. issue 18 of special report. Iowa State College. Agricultural Experiment Station.

Daradjat, S. R. (2007). Skripsi, sosialisasi keamanan dan ketertiban polisi resort kota bandung timur dalam membentuk sikap masyarakat terhadap keamanan dan ketertiban lingkungan. Bandung: Fakultas Ilmu Komunikasi Universitas Padjadjaran.

Effendy, U. O.(1994). Ilmu komunikasi teori dan praktek. Bandung: Remaja Rosdakarya. (2002). Hubungan masyarakat.

Bandung: Remaja Rosdakarya.

Jurnal Komunikasi dan Informasi, Volume 8, Nomor 2, Oktober 2009 - April 2010, Fakultas Ilmu Komunikasi Universitas
Padjadjaran.

Kasali, R. (2007). Membidik pasar Indonesia segmentasi targeting positioning. Jakarta: Gramedia Pustaka Utama.

Kompas. (2014). Babinkamtibmas: polri untuk jaga keamanan dan lingkungan masyarakat. Diakses dari http://nasional.kompas. $\mathrm{com} / \mathrm{read} / 2014 / 06 / 06 / 1604509 /$ Babinkamtibmas.Polri.untuk. Jaga.Keamanan.dan.Lingkungan. Masyarakat 17 September 2014.

Nasution. (1996). Metodologi penelitian naturalistik kualitatif. Bandung: Tarsitotion.

Rakhmat, J. (1999). Metode penelitian komunikasi. Bandung: Remaja Rosdakarya. (2005) Metode penelitian komunikasi. Bandung: Remaja Rosdakarya.

Rumanti, A. Sr. Maria, OSF (2002). Dasardasar public relations teori dan praktik". Jakarta: Gramedia Widiasarana Indonesia.

Ruslan, R. (2004). Kiat dan strategi kampanye public relations, Jakarta: RajaGrafindo Persada.

Sugiono (2002). Statistika untuk penelitian. Bandung: Alfabeta.

Suprapto (2013). Metodologi penelitian ilmu pendidikan dan ilmu-ilmu pengetahuan sosial. Yogyakarta: Center for Academic Publishing Service.

Tondowidjojo, J. (2002). Dasar dan arah public relations, Jakarta: Grasindo.

Undang-undang Kepolisian Negara Republik Indonesia Nomor 2 Tahun 2002 pada Bab III pasal 13.

Warta Polisi, 2006, Citra positif kepolisian, Bandung.

Wright, C. R. (1988). Mass communication: a sociological perspective. Terjemahan sosiologi komunikasi massa, Jalaludin Rakhmat, Bandung: Remaja Rosdakarya.

Volume 18 of Special report, Iowa Agricultural Experiment Station Ames. 